\title{
Effects of Principals' Support on Teachers' Self -Efficacy in Integrating e-learning in the Jordanian Discovery Schools
}

\author{
Khader AL-Rawajfih \\ School of Educational Studies, Universiti Sains Malaysia \\ Tel: 60-01-7468-5690 E-mail:khader_k_alrawajfih@yahoo.com \\ Soon Fook Fong (Corresponding author) \\ School of Educational Studies, Universiti Sains Malaysia \\ Tel: 60-01-2525-4955 E-mail: sffong05@gmail.com \\ Sharifah Norhaidah Syed Idros \\ School of Educational Studies, Universiti Sains Malaysia \\ Tel: 60-4-04-658-5414 E-mail: snsi@usm.my
}

\begin{abstract}
This study examines the effect of perceptions of principals' support of teachers in Jordan Discovery schools on the integration of e-learning into their teaching. 350 teachers were randomly stratified from a total of 2,389 teachers from all the secondary Discovery schools in the four districts (strata) of the capital, Amman. The dependent variable was the integration of e-learning. The independent variable was the perception on the Principals' support needed for the integration of e-Learning and the moderating variable was the gender and teaching experiences. The responses from the survey were analyzed with descriptive statistics and two-way ANOVA. The findings of this study exhibit moderate levels of self-efficacy. From the perspective of self-efficacy, there were significant differences among the means for main effect for both teachers' teaching experience and gender on the integration of e-learning.
\end{abstract}

Keywords: Principals' Support, E-learning integration

\section{Introduction}

In this study we explored the effect of Principals' support on teachers' self-efficacy on the levels of e-Learning integration in Jordanian schools for informing a professional development program to make certain that the integration effort is optimized, effective and sustainable. By this is meant, that the individual's self-efficacy and how they develop as they learn about the innovation will be studied to be used by the relevant parties to set up a strong mentoring program so that Jordan can enhance its e-Learning culture. The objectives of this study are as follows

1) To determine the level of perception on principal's support on the integration of e-Learning among teachers in Jordanian discovery schools

2) To investigate the significant difference of perception on the principal's support on the integration of e-Learning based on teachers' teaching experiences and gender in Jordanian discovery schools.

Principals are the main agent in schools and the effective school leader is extremely important in determining the level of technology integration in classrooms in particular and school in general. The principal's support as a vital part of the educational system is extremely important (Oberg, 1995). A study by Plomp, Pelgrum, \& Steerneman (1990) found that one of the barriers to computer use in their three case study schools was a lack of direction from the administration at school and national level. Lack of support from leaders was a key obstacle to successful integration of computers in education (Pelgrum \& Plomp 1991). Educational systems worldwide face increasing pressure to use e-Learning to enhance teaching, learning, and administration jobs.

School principal as building level leaders are important people to make a change happen and take responsibility for technology or any kind of innovations (Rockman \& Sloan, 1993). In addition, Rockman and Sloan (1993) suggest that principal as building level leaders will increasingly take responsibility for technology and other innovations in their schools.

School principal must understand what is available, how it might be used in schools, and where to get advice on 
issues such as developing internal networks and providing Internet access to classrooms. Garcia, Johnson and Dallman (1997) also argue that the principal' vision and leadership are an important indicator of an effective integration of technology into schools. Principal must know how they can stay up-to-date with the latest technology, and they must be knowledgeable about a wide range of e-Learning issues in their schools. Instead, e-Learning has fundamentally changed the work of principals' by facilitating new types of work and improving older work patterns. Some of the changes are merely improvements in traditional practices, such as using spreadsheets to create budgets and accounts, e-mail for communication, and word processing software for writing (Gurr, 2001).

Although the principal struggle to provide adequate e-Learning resources, good resources can prompt dramatic change in student proficiency with technology (Gurr, 2001). The principal use of technology is also included as part of the leadership component since principal foster credibility and respect by engaging in technology activities such as communicating to the staff via email, demonstrating the use of desktop presentation to the faculty, showing a student how to keep a writer's journal with a word processing program, or describing a technology-enhanced teaching strategy (Maurer, 1998). Carlson (2002) added that the principals' important role is to support teachers' by giving them adequate time to attend training courses of technology integration.

The JEI (Jordan Education Initiative) has piloted two ICT (information Communication and Technology) models for the delivery and use of the e-content, computer labs, portable laptop computers and projectors issued to teachers for use in classrooms (Education Development Center, Inc., 2008). In each discovery school there are at least two labs, with $512 \mathrm{~kb}$ connectivity through ADSL lines and broadband connections; these are connected under the National Broadband Network. In classrooms using e-content wireless access points and projectors are available. Computer labs are reconfigured as classrooms each about $50 \mathrm{~m}^{2}$ with around 20 workstations per lab. In the discovery schools laboratories the desktop computers are relatively new and well-maintained; this is less true for other ERFKE schools, many of which have fewer labs, with fewer and older computers.

There is cooperation between the JEI and the JMOE (Jordanian Ministry of Education) for providing the Discovery schools with e-Learning infrastructure and other resources (Education Development Center, Inc., 2008). These e-Learning resources are provided to all schools in the Kingdom besides the Discovery schools; however, the JEI brings additional resources. Two basic e-Learning tools are used by the JEI, these are, computer labs and teacher laptop computers. Each Discovery school has six or seven laptop computers, and most of the Discovery schools have been provided with multiple computer labs. The JEI provided teachers with laptops and projectors to use in the classroom. The JMOE is transferring to a broadband network. All the Discovery schools, recently, are connected either to the broadband network or with ADSL (Asymmetric Digital Subscriber Line) connections (Education Development Center, Inc., 2008).

\section{Research Method}

This research looks into the perception on the principal's support of secondary teachers in the Jordanian Discovery schools regarding the integration of e-Learning in teaching and learning. In the quantitative methods four sets of questionnaires will be used in this study.

The target population for this study are Jordanian teachers in the first, second, third and fourth districts of 100 secondary Discovery schools in Amman. These schools are chosen specifically due to the government's interest in experimenting integration e-Learning and spreading this innovation over 100 Discovery schools as a test bed to ensure an effective deployment of the ICT solutions at the Ministry of Education's Schools through the Discovery School Track. Six e-curricula (Math, Science, Arabic, ICT, English as a Foreign Language and Civics) were developed and deployed, in different phases, at the Discovery schools. The schools are being supported with infrastructure and devices to ensure success in implementing the integration of e-Learning in these schools.

The researchers chose to focus on these four districts because they represent the urban side of the capital in which the e-Learning infrastructure has been installed more rapidly than other parts of Jordan. Also, these four districts are in location to the researcher in terms of access and delivery of the survey.

Table 1 provides a summary of the numbers of Discovery schools and teachers in the four districts of Amman.

\subsection{Research Questions}

2.1.1 What is the level of perception on principal's support on the integration of e-Learning among teachers in the Jordanian discovery schools?

Based on the interpretation of index and mean scores by Green et al. (1997), the mean scores of the integration of e-Learning can be categorized into low, moderate or high level (Table 2). Thus, it can be interpreted that the level of perception of principal's support on the integration of e-Learning among teachers in Jordanian discovery 
school is in the moderate category (Table 3). The same pattern of the result appears when the data is analyzed based on the gender and teaching experiences (Table 4 and 5).

2.1.2 Is there a significant difference of perception on the principal's support on the integration of e-Learning based on teachers' teaching experiences and gender in Jordanian discovery schools?

A two-way ANOVA between group analysis of variance was conducted to explore the impact of teachers' gender and teaching experiences on the teachers' perception towards principal's support on the integration of e-Learning. There were no statistically significant differences for main effect of teachers' gender, $F(3,342)=0.105, \mathrm{p}=$ 0.746. There were no statistically significant differences for main effect of teaching experiences, $\mathrm{F}(3,342)=$ $0.152, \mathrm{p}=0.928$. There was no statistically significant interaction effect between teacher's gender and teaching experience from the aspect of integration of e learning, $F(3,342)=0.583, \mathrm{p}=0.626$.

\section{Discussion}

The result of descriptive statistics showed that the level of perception on the principal's support on the integration of e-learning among teachers in Jordanian discovery school was moderately positive (M=3.12, S.D. $=0.376)$. The similar pattern of the findings were also appeared when the data was analyzed across male $(\mathrm{M}=$ 3.11, S.D. $=0.383)$ and female $(M=3.12$, S.D. $=0.373)$ teachers. The moderately positive results were also appeared when the data was analyzed based on years of teaching experiences accordingly. Those findings were referred to four classifications of teaching experiences, namely: 1 to 5 years of teaching experiences $(\mathrm{M}=3.11$, S.D. $=0.361), 6$ to 10 years of teaching experiences $(M=3.15$, S.D. $=0.409), 11$ to 15 years of teaching experiences $(M=3.10$, S.D. $=0.357)$ and 16 to 20 years of teaching experiences $(M=3.09$, S.D. $=0.334)$. Thus, based on the descriptive statistical analysis results, it can be concluded that the level of perception on the principal's support on the integration of e-learning was moderately positive across teachers' gender and years of teaching experiences.

The findings of descriptive statistical analysis test were also triangulated by the findings of the inferential statistical test result. The results of inferential statistical tests using two-way ANOVA test showed that there were no significant differences on the level of perception on principal's support on the integration of e-learning between groups of teachers who have different years of teaching experiences, $F(3,342)=0.152, p>0.05$; and between male and female teachers, $\mathrm{F}(3,342)=0.105, \mathrm{p}>0.05$. Furthermore, the two ANOVA test revealed that there was no statistically significant interaction effect between category of teaching experience and gender based on the perception on the principal's support on the integration of e-learning among teachers in Jordanian discovery school, $\mathrm{F}(3,342)=0.583, \mathrm{p}>0.05$. Thus, it can be concluded that mean scores of the perception on the principal's support on the integration of e-learning were similar across teacher's gender and years of teaching experiences.

Due to the reason that the principal's support perceived by teachers are at the moderate level, thus, it can inferred that teachers at the Jordanian Discovery schools did not feel that they have enough support to integrate e-learning in their teaching process. This findings can be related with the findings by Plomp, Pelgrum, and Steerneman (1990) in their study. They found that one of the main barriers related to computer use was a lack of direction from the administration at school. Lack of support from leaders was key obstacle to successful integration of computers in education (Pelgrum \& Plomp, 1991).

The inadequate support from the principal probably can be also viewed from the aspect of funding, training deficiencies, inadequate access, time constraints, the lack of computers in schools, the concerns over academic standards and lack of technical support as barriers which affect e-learning integration (Pajo \& Wallace, 2001; Abbitt \& Klett, 2007). Those problems could be solved if more supports were given by the principal for the integration of e-learning. This is supported by Rockman and Sloan (1993) who stated that the school principal are the building level leaders who are able to make change happen and take responsibility for technology or any kind of innovations.

The findings of this study showed that there are supports given by the principal for the integration of e-learning, however, the level of the support are perceived not to be adequate enough. It is suggested that more initiatives should be taken by the principal for supporting the integration of e-learning so that the level of the support given by the principal will move from moderate level to high level. Garcia et al, (1997) argue that the principals themselves should have the initiative to equip with the skills about the latest technology and knowledge about a wide range of e-learning issues in their schools. The principal use of technology is also included as part of the leadership component since principal foster credibility and respect by engaging in technology activities such as communicating to the staff via email (Maurer, 1998). The principal also must know how to demonstrate the use of desktop presentation to the faculty and show student how to keep a writer's journal with a word processing 
program, or describing a technology-enhanced teaching strategy (Maurer, 1998). Carlson (2002) added that the principals also must give teachers adequate time to attend training course of technology integration.

\section{Implication}

The findings suggest that the principal play an important role in encouraging the teachers for the integration of e-learning. This implies the vital role of focused-training for teachers and principal should also be trained specifically to manage the culture of integration of e-learning among teachers. Thus, the principal also should be equipped with skills and knowledge so that they will serve as a model and a 'champion' for the integration of e-learning to support the school community. Although currently there are workshops organized for the school principal for integration of e-learning, nevertheless, the workshop should not be done as a one-shot workshop, but as an on-going workshop which monitor the progress of the principal in supporting the teachers for the integration of e-learning.

\section{References}

Abbitt, J. T. \& Klett, M. D. (2007). Identifying influences on attitudes and self-efficacy beliefs towards technology integration among pre-service educators. Electronic Journal for the Integration of Technology in Education, 6, p.28-42.

Carlson, S. (2002). Teacher professional development in the use of technology. In Haddad, w. and Draxler, A (ed). Technologies for education: potentials, parameters, and prospects.

Education Development Center, Inc. (2008). Evaluation of the Jordan Education Initiative. Report: Task1 The emerging paradigm of teaching and learning in Discovery schools. Jordan: USAID.

Garcia, A., Johnson, A. \& Dallman, J. (1997). The role of the principal in technology integration. [Online]. [Accessed 14 ${ }^{\text {th }}$ Sept 2007] Available from World Wide Web: http://www.coe.uh.edu/insitelelec_pub/HTML1997/td_garc.ht

Green, J. C. \& Caracelli, V. J. eds. (1997). Advances in mixed-method evaluation: The challenges and benefits of integrating diverse paradigms. In New directions for evaluation, ed. American Evaluation Association. San Francisco: Jossey-Bass.

Gurr, D. (2001). Principals, Technology, and Change. The Technology Source Archives at the University of North Carolina.

Hall, G.E. and S.M., Hord. (1987). "Change in schools: Facilitating the process", Albany, NY: State University of New York Press.

Maurer, M. M. (1998). Computer anxiety correlates and what they tell us: a literature review. Computers in Human Behavior, 10 (3), p.369-376.

Oberg, D. (1995). Principal support: What does it mean to teacher- librarians? The Annual conference of the International association of school librarianship., July 17-21, Worcester, England.

Pajo, K. \& Wallace, C. (2001). Barriers to the Uptake of Web-based Technology by University Teachers. The Journal of Distance Education, 16(1).

Pelgrum, W. \& Plomp, T. (1991). The use of computers in education worldwide. Oxford: Pergamon Press.

Plomp, T., Pelgrum, W. \& Steerneman, A. (1990). Influence of computer use on schools? curriculum: Limited integration. Computers and Education 14(2), p.159-171.

Rockman, S. and Sloan, K. R. (1993). A Program that Works: Indiana's Principals' Technology Leadership Training Program. Indiana State Department of Education.

Rogers, E. M. (1995). "Diffusion of innovations", $4^{\text {th }}$ ed. New York: The Free Press. 
Table 1. Discovery schools and teachers in the four districts of Amman (JMOE, 2009)

\begin{tabular}{lllll}
\hline No. & District & School & Teachers \\
\hline 1. & Amman First district & 47 & 1162 \\
\hline 2. & Amman Second district & 32 & 744 \\
\hline 3. & Amman Third district & 2 & 97 \\
\hline 4. & Amman Fourth district & 19 & 386 \\
\hline Total & & & 2389 \\
\hline
\end{tabular}

Table 2. Indicator of mean scores for the perception towards the principal's support on the integration of e-Learning

\begin{tabular}{ll}
\hline Range & Indicator \\
\hline $1.00-2.33$ & Low \\
$2.34-3.67$ & Moderate \\
$3.68-5.00$ & High \\
\hline
\end{tabular}

Table 3. Level of the perception towards the principal's support on the integration of e-Learning among teachers in Jordanian discovery school

\begin{tabular}{llll}
\hline & Mean Score & $\begin{array}{l}\text { Standard } \\
\text { Deviation }\end{array}$ & Level \\
\hline Perception on principal's support & 3.12 & 0.376 & Moderate \\
\hline
\end{tabular}

Table 4. Level of the perception towards the principal's support on the integration of e-Learning among teachers in Jordanian discovery school based on teachers' gender

\begin{tabular}{|c|c|c|c|c|c|}
\hline & & Gender & Mean Score & $\begin{array}{l}\text { Standard } \\
\text { Deviation }\end{array}$ & Level \\
\hline \multirow{2}{*}{\multicolumn{2}{|c|}{$\begin{array}{l}\text { Perception } \\
\text { support }\end{array}$}} & Male & 3.11 & 0.383 & Moderate \\
\hline & & Female & 3.12 & 0.373 & Moderate \\
\hline
\end{tabular}

Table 5. Level of the perception towards the principal's support on the integration of e-Learning among teachers in Jordanian discovery school based on teaching experiences

\begin{tabular}{lllll}
\hline & $\begin{array}{l}\text { Teaching } \\
\text { experiences }\end{array}$ & Mean Score & $\begin{array}{l}\text { Standard } \\
\text { Deviation }\end{array}$ & Level \\
\hline \multirow{3}{*}{\begin{tabular}{c} 
Perception on principal's $\begin{array}{c}\text { 1 to 5 years } \\
\text { support }\end{array}$ \\
\cline { 2 - 5 }
\end{tabular}} & 6 to 10 years & 3.11 & 0.361 & Moderate \\
\cline { 2 - 5 } & 11 to 15 years & 3.10 & 0.409 & Moderate \\
\cline { 2 - 5 } & 16 to 20 years & 3.09 & 0.357 & Moderate \\
\hline
\end{tabular}

